\title{
REPEATABILITY OF BIOMETRIC CHARACTERISTICS OF JUÇARA PALM FRUIT
}

\author{
REPETIBILIDADE DE CARACTERÍSTICAS BIOMÉTRICAS DE FRUTOS DE \\ PALMITO JUÇARA
}

\author{
Tiago de Souza MARÇAL ${ }^{1}$; José Henrique Soler GUILHEN ${ }^{1}$; \\ Wagner Bastos dos Santos OLIVEIRA ${ }^{2}$; Marcia Flores da Silva FERREIRA ${ }^{3}$; \\ Marcos Deon Vilela de RESENDE ${ }^{4}$; Adésio FERREIRA ${ }^{5}$
}

1. Mestrando em Genética e Melhoramento, Departamento de Produção Vegetal, Universidade Federal do Espírito Santo - UFES, Alegre, ES, Brasil; 2. Mestre em Produção Vegetal, Departamento de Produção Vegetal - UFES, Alegre, ES, Brasil; 3. Professora, Doutora Associada, Departamento de Biologia CCENS/UFES, Alegre, ES Brasil; 4. Empresa Brasileira de Pesquisa Agropecuária, Centro Nacional de Pesquisa de Florestas, Colombo, PR, Brasil; 5. Professor, Doutor Associado, Departamento Produção Vegetal, CCAE/UFES, Alegre, ES Brasil. adesioferreira@gmail.com

\begin{abstract}
Juçara is a plant that occurs in the Brazilian Atlantic Forest which presents high ecological importance to the biodiversity and is present on the list of endangered species. The fruits are known as super fruits because they present chemical characteristics of great importance. Due to its elevated economic importance and for the low number of researches with this species, the first step is to make the pre-breeding of the species. This consists in morphological characterization, which is very dependent on time and labour. Thus, the decrease of the number of evaluated measurements by individual is of great importance to the phases of pre-breeding and breeding. The objective of this work was to obtain estimates of the coefficients of repeatability and determination of six Euterpe edulis fruit characteristics to enable the prediction of the necessary number of measurements required to achieve given levels of certainty for the real values for each of the six fruit characteristics. The performances of various methods for repeatability estimation were compared. The characteristics longitudinal diameters of the fruits, longitudinal diameters of the seeds, equatorial diameters of the fruits, equatorial diameters of the seeds, fruit weights and seed weights of juçara palm fruits were measured, and the deviances, the coefficients of repeatability, the coefficients of determination, and the necessary numbers measurements for an accurate prediction of the real value of the population were estimated. The methods used do not differ as to estimate the repeatability coefficient to the longitudinal diameter characteristics of the fruit, seed equatorial diameter, fruit mass and seed mass. With 95\% reliability is possible to use four (4) for mass measurements of fruit and five (5) measurements for longitudinal diameter of fruit, seed equatorial diameter, fruit mass and seed mass.
\end{abstract}

PALAVRAS-CHAVE: Euterpe edulis. Plant breeding. Biometrics.

\section{INTRODUCTION}

The juçara palm (Euterpe edulis Martius) is a native species of the Atlantic forest (CEMBRANELI et al., 2009) of significant ecological and economic importance (GATTI et al., 2011). The juçara palm is currently at risk of extinction (GANEM, 2010), mainly because of the illegal extraction of hearts of palm in forest remnants (BARROSO et al., 2010).

Juçara plays an important ecological role because it produces large quantitie of fruit that are consumed by a vast number of birds and mammals during periods of general food shortage (FADINI et al., 2009, GENINI et al., 2009). In addition to its ecological importance, juçara also has potential for fruit production, with yields ranging between 216 and 528 bunches ha $^{-1}$ year $^{-1}$ of approximately 6 to 8 $\mathrm{kg}$ of fruits bunch ${ }^{-1}$ (SEOANE et al., 2005).

The pulp of jucara fruits is characterized by high levels of functional compounds and antioxidants, which classifies the juçara as a "super fruit" (SANTOS et al. 2014). Additionally, the juçara fruits are also used as raw materials for obtaining natural dye (FIGUEREDO et al., 2008), pulp, juice, medication, cosmetics, and functional foods (FELZENSZWALB et al., 2013).

To obtain higher juçara fruit yields, the cultive of more highly adapted and productive genotypes is required. This thorough step involves activities such as the harvesting of genotypes and the identification desirable traits, genes, or sets of genes in the available germplasm (MANFIO et al., 2011).

To optimise the costs, time, and use of labour for field campaigns without losses to the selection efficiency of subsequent steps (CHIA et al., 2009) it is important to know the number of fruit to be sampled from each genotype (MANFIO et al., 2011). The adequate number of samples can be estimated by the coefficient of repeatability, which represents the correlation amongst the repeated 
measurements collected from the same entity (CRUZ et al., 2012).

The repeatability coefficient can be defined as the ratio of the total phenotypic variation that is assigned to the permanent phenotypic variation (genetic + permanent environment) and is intended to measure the response of the phenotypic consistency after several measurements. The coefficient of repeatability is of great importance for breeding studies and several authors have used this concept for studies of traits conducted for numerous perennial species, such as guarana (NASCIMENTO FILHO et al., 2009), bacuri (SILVA et al. 2009), plum tree and peach tree (DANNER et al., 2010), açaí palm (FARIAS NETO et al., 2011), jatropha (ROCHA et al., 2012), and peach palm (BERGO et al., 2013).

This study aimed to obtain estimates of the coefficients of repeatability and of determination to predict the required number of measurements required to provide a given certainty level for estimate of the values in biometric analysis of the $E$. edulis individuals. For this, the methods for estimating the coefficient of repeatability were compared by evaluating six characteristics of $E$. edulis fruit.

\section{MATERIAL AND METHODS}

Fruits of 198 juçara genotypes were collected amongst 20 forest fragments within the southern region (municipalities: Muqui, Mimoso, and Jerônimo Monteiro) and Caparaó region (municipalities: Alegre, Guaçuí, and Ibitirama) of Espírito Santo State, Brazil. Fruits of ten genotypes were collected from each fragment, except only eight genotypes were harvested from one of the fragments within the municipality of Guaçuí.

A total of 25 fruits of each genotype were evaluated for the following characteristics: the longitudinal and equatorial diameters of the fruits and seeds (FLD, SLD, FED, and SED), in mm, using a digital calliper with a $0.01-\mathrm{mm}$ precision; and the fruit and seed weights (FW and $\mathrm{SW}$ ), in grams (g), using an electronic scale with a $0.01-\mathrm{g}$ precision.

For these characteristics, the deviance and the coefficients of repeatability $(\hat{\mathrm{r}})$ and determination $\left(\hat{\mathrm{R}}^{2}\right)$ were estimated, and the number of necessary measurements $\left(\eta_{0}\right)$ required for an

$$
\begin{gathered}
\mathrm{D}=-2 \ln (\mathrm{L})[5] \\
\ln (\mathrm{L})=-\frac{1}{2} \ln \left|\mathrm{X}^{\top} \mathrm{V}^{-1} \mathrm{X}\right|-\frac{1}{2} \ln |\mathrm{V}|-\frac{1}{2}(\mathrm{y}-\mathrm{Xm})^{\top} \mathrm{V}^{-1}(\mathrm{y}-\mathrm{Xm})[6]
\end{gathered}
$$

accurate estimate of the real value for the individuals was predicted.

The deviance analysis was performed using the restricted maximum likelihood (REML) method, employing a basic repeatability model that assumes the absence of design effects and can be written in matrix form according to equation [1], with the distribution of the mean [2] and the variances [3] and [4] (Resende, 2002a):

$\mathrm{y}=\mathrm{Xm}+\mathrm{Zp}+\varepsilon[1]$

$\mathrm{E}\left[\begin{array}{c}\mathrm{y} \\ \mathrm{p} \\ \varepsilon\end{array}\right]=\left[\begin{array}{c}\mathrm{Xm} \\ 0 \\ 0\end{array}\right][2]$

$\operatorname{Var}\left[\begin{array}{l}\mathrm{y} \\ \mathrm{p} \\ \varepsilon\end{array}\right]=\left[\begin{array}{ccc}\mathrm{V} & \mathrm{Z}^{\prime} \mathrm{P} & \mathrm{R} \\ \mathrm{P}^{\prime} \mathrm{Z} & \mathrm{P} & 0 \\ \mathrm{R} & 0 & \mathrm{R}\end{array}\right]$ [3]

$\mathrm{P}=\mathrm{I} \sigma_{\mathrm{p}}^{2}$

$\mathrm{R}=\mathrm{I} \sigma_{\mathrm{e}}^{2}$

$\mathrm{V}=\mathrm{ZPZ}+\mathrm{R}$

$\mathrm{y} \mid \mathrm{m}, \mathrm{V} \sim \mathrm{N}(\mathrm{Xm}, \mathrm{V})$

$\mathrm{p} \mid \mathrm{P}, \sigma_{\mathrm{p}}^{2} \sim \mathrm{N}(0, \mathrm{P})$

$\varepsilon \mid \mathrm{R}, \sigma_{\mathrm{e}}^{2} \sim \mathrm{N}(0, \mathrm{R})$

where: $\mathbf{y}$ is the vector of the variable to be analysed; $\mathbf{m}$ is the vector of the measurement effects, which are assumed to be fixed and added to the overall mean; $\mathbf{p}$ is the vector of the permanent phenotypic effects, which are assumed to be random; $\boldsymbol{\varepsilon}$ is the vector of random error; $\mathbf{X}$ is the incidence matrix for the fixed effects; $\mathbf{Z}$ is the incidence matrix for the permanent phenotypic effects; $\mathbf{V}$ is the matrix of the variance and covariance of $y ; \mathbf{P}$ is the matrix of the variance and covariance for the permanent phenotypic effects; $\mathbf{R}$ is the matrix of the residual variance and covariance; $\sigma_{p}^{2}$ is the variance of the permanent phenotypic values (genetic variation + permanent environmental variation); and $\boldsymbol{\sigma}_{\mathrm{e}}^{2}$ is the residual variance attributed to the temporary environment. Based on model [1], the deviance (D) is given by [5] (RESENDE, 2002a): 
where: $\ln (\mathbf{L})$ is the maximum point of the logarithmic function of the restricted maximum likelihood (PATTERSON; THOMPSON, 1971); y is the vector of the variable to be analysed; $\mathbf{m}$ is the vector of the measurement effects, which are assumed to be fixed and added to the overall mean; $\mathbf{X}$ is the incidence matrix for the fixed effects; and $\mathbf{V}$ is the matrix of the variance and covariance of $y$.

The estimates of the statistical likelihood ratio test (LRT) for the variables under study were obtained using [7] (RESENDE, 2002a):

$$
\mathrm{LRT}=\left|-2 \ln \left(\hat{\mathrm{L}}_{\mathrm{PPE}}\right)+2 \ln \left(\hat{\mathrm{L}}_{\mathrm{FM}}\right)\right|[7]
$$

where: $\hat{\mathbf{L}}_{\mathbf{P P E}}$ is the estimated maximum point of the restricted likelihood function for the reduced model (without permanent phenotypic effects), and $\hat{\mathbf{L}}_{\mathbf{F M}}$ is the estimated maximum point of the restricted likelihood equation for the full model (with permanent phenotypic effects).

The methods adopted for estimating the coefficients of repeatability were as follows: restricted maximum likelihood (REML) using the basic repeatability model that assumes the absence of design effects (RESENDE, 2002a), principal components method based on the correlation (PCC) and covariance matrices (PCCV) (ABEYWARDENA, 1972), and structural analysis based on the correlation (SAC) and covariance matrices (SACV) (Mansour et al., 1981) amongst the repeated measurements.

Based on the adopted model [1], the repeatability coefficient is given by [8] (RESENDE, 2002b):

$$
\begin{aligned}
& \hat{\mathrm{r}}=\frac{\sigma_{\mathrm{p}}^{2}}{\sigma_{\mathrm{e}}^{2}+\sigma_{\mathrm{p}}^{2}}[8] \\
& \sigma_{\mathrm{e}}^{2}=\frac{\mathrm{y}^{\prime} \mathrm{y}-\hat{\mathrm{m}}^{\prime} \mathrm{X}^{\prime} \mathrm{y}-\hat{\mathrm{p}}^{\prime} \mathrm{Z}^{\prime} \mathrm{y}}{\mathrm{N}-\mathrm{r}(\mathrm{X})}[9] \\
& \sigma_{\mathrm{p}}^{2}=\frac{\hat{\mathrm{p}} \hat{\mathrm{p}}+\hat{\sigma}_{\mathrm{e}}^{2} \wedge \operatorname{tr}\left(\mathrm{C}^{22}\right)}{\mathrm{S}}[10] \\
& {\left[\begin{array}{cc}
X^{\prime} X & \mathrm{X}^{\prime} \mathrm{Z} \\
\mathrm{Z}^{\prime} \mathrm{X} & \left.\mathrm{Z}^{\prime} \mathrm{Z}+\mathrm{I}\left(\frac{\hat{\sigma}_{\mathrm{e}}^{2}}{\hat{\sigma}_{\mathrm{p}}^{2}}\right)\right]^{-1}=\left[\begin{array}{ll}
\mathrm{C}^{11} & \mathrm{C}^{12} \\
\mathrm{C}^{21} & \mathrm{C}^{22}
\end{array}\right]
\end{array}\right]}
\end{aligned}
$$

where: $\sigma_{\mathrm{e}}^{2}$ is the estimated residual variance that can be obtained using the iterative estimator given by [9]; for which, $\mathbf{N}$ is the total number of data and $\mathbf{r}(\mathbf{X})$ is the rank of the matrix $X ; \boldsymbol{\sigma}_{\mathbf{p}}^{2}$ is the estimated variance of the permanent phenotypic values (genetic variation + permanent environmental variation) that can be obtained using the iterative estimator given by [10]; for which, tr represents the matrix trace operation and $\mathbf{S}$ is the number of columns of matrix Z. Additionally, this estimator depends on $\mathbf{C}^{22}$ [11], which is the sub-matrix of the generalised inverse of the matrix of the mixed model equation coefficients.

For the PCC method, the coefficient of repeatability is given by [12] (RUTLEDGE, 1974):

$$
\begin{gathered}
\hat{\mathrm{r}}=\frac{\hat{\lambda}_{\hat{\mathrm{R}}}-1}{\eta-1}[12] \\
\hat{\mathrm{R}}=\left[\begin{array}{cccc}
1 & \hat{\rho}_{12} & \cdots & \hat{\rho}_{1 \mathrm{j}} \\
\hat{\rho}_{21} & 1 & \cdots & \hat{\rho}_{2 \mathrm{j}} \\
\vdots & \vdots & \ddots & \vdots \\
\hat{\rho}_{\mathrm{i} 1} & \hat{\rho}_{\mathrm{i} 2} & \cdots & 1
\end{array}\right]_{\eta \times \eta}
\end{gathered}
$$

$|\hat{\mathrm{R}}-\lambda \mathrm{I}|=0[14]$

where: $\eta$ is the number of measurements performed in the experiment and $\hat{\lambda}_{\hat{\mathbf{R}}}$ is the estimate of the largest eigenvalue associated with the estimate of the correlation matrix amongst the repeated measurements ( $\hat{\mathbf{R}}$ ) [13]; the estimate is obtained by solving the model shown in [14].

The PCCV method employs the estimator described by [15] for the determination of the coefficient of repeatability (MORRISON, 1976):

$\hat{r}=\frac{\hat{\lambda}_{\hat{\Gamma}}-\hat{\sigma}_{y}^{2}}{\hat{\sigma}_{y}^{2}(\eta-1)}[15]$

$\hat{\sigma}_{\mathrm{y}}^{2}=\frac{1}{\eta} \sum_{\mathrm{i}=\mathrm{j}}^{\eta} \hat{\sigma}_{\mathrm{ij}(\hat{\Gamma})}^{2}[16]$

$\hat{\Gamma}=\left[\begin{array}{cccc}\hat{\sigma}_{11}^{2} & \sigma_{12} & \cdots & \sigma_{1 j} \\ \sigma_{21} & \hat{\sigma}_{22}^{2} & \cdots & \sigma_{2 j} \\ \vdots & \vdots & \ddots & \vdots \\ \sigma_{i 1} & \sigma_{i 2} & \cdots & \hat{\sigma}_{\eta \eta}^{2}\end{array}\right]_{\eta \times \eta}$

$|\hat{\Gamma}-\lambda I|=0 \quad[18]$

where: $\eta$ is the number of measurements performed in the experiment; $\hat{\sigma}_{\mathbf{y}}^{2}$ [16] is an estimator for the sum of the residual variance and the permanent environmental variance; and $\hat{\lambda}_{\hat{\Gamma}}$ is the estimate of the largest eigenvalue associated with the estimated covariance matrix amongst the repeated measurements $(\hat{\Gamma})$ [17]; the estimate is obtained by solving the model shown in [18].

The repeatability coefficient can be obtained by the SAC method, as described by [19] (Mansour et al., 1981): 


$$
\hat{\mathrm{r}}=\frac{\alpha \hat{\mathrm{R}} \alpha-1}{\eta-1}=\frac{2}{\eta(\eta-1)} \sum_{\mathrm{j}} \sum_{<\mathrm{j}^{\prime}} \hat{\rho}_{\mathrm{j} j^{\prime}}
$$

where: $\alpha$ is the eigenvector associated with the greatest eigenvalue of the estimated correlation matrix amongst the repeated measurements $(\hat{\mathbf{R}}) ; \boldsymbol{\eta}$ is the number of measurements performed in the experiment, and $\hat{\boldsymbol{\rho}}_{\mathrm{j} \mathbf{j}}$ represents the estimates of the correlations amongst the repeated measurements.

The SACV method employs the estimator shown in [20] for the determination of the coefficient of repeatability (MANSOUR et al., 1981):

$\hat{r}=\frac{\gamma \hat{\Gamma} \gamma-\hat{\sigma}_{y}^{2}}{\hat{\sigma}_{y}^{2}(\eta-1)}=\frac{1}{\eta(\eta-1) \hat{\sigma}_{y}^{2}} \sum_{j} \sum_{\neq j^{\prime}} \hat{\sigma}_{j j^{\prime}}$

where: $\boldsymbol{\gamma}$ is the eigenvector associated with the greatest eigenvalue of the estimated covariance matrix amongst the repeated measurements $(\hat{\Gamma})$; $\hat{\sigma}_{\mathrm{y}}^{2}$ is an estimator for the sum of the residual variance and the permanent environmental variance; $\eta$ is the number of measurements performed in the experiment; and $\hat{\boldsymbol{\sigma}}_{\mathrm{jj}}$ represents the estimated covariance amongst the repeated measurements.

The estimated coefficient of determination $\left(\hat{\mathrm{R}}^{2}\right)$, which represents the certainty of the prediction of the real value of the individuals for the variables analysed based on the $\eta$ measurements, was obtained by solving [21] (CRUZ et al., 2012):

$$
\mathrm{R}^{2}=\frac{\eta \hat{\mathrm{r}}}{1+\hat{\mathrm{r}}(\eta-1)}[21]
$$

where: $\eta$ is the number of measurements performed in the experiment and $\hat{\mathbf{r}}$ represents the estimated coefficient of repeatability.

The numbers of necessary measurements $\left(\eta_{0}\right.$ ) for accurately predicting the real values of the individuals for the variables analysed were calculated using equation [22] (CRUZ et al., 2012):

$\eta_{0}=\frac{\mathrm{R}^{2}(1-\hat{\mathrm{r}})}{\left(1-\mathrm{R}^{2}\right) \hat{\mathrm{r}}}[22]$

where: $\mathbf{R}^{2}$ is the coefficient of determination and $\hat{\mathbf{r}}$ is the estimated coefficient of repeatability.

The analyses were performed using the $\mathrm{R}$ software environment (TEAM, 2015).

\section{RESULTS AND DISCUSSION}

There were significant differences between the deviances of the reduced model (without permanent phenotypic effect) and the full model (with permanent phenotypic effect), known as the likelihood ratio tests (LRTs), for all of the variables (1\%-probability level by the chi-square test $\left(\chi^{2}\right.$; Table 1).

Table 1. Deviance analysis (DEVANA) for fruit longitudinal diameter (FLD), fruit equatorial diameter (FED), seed longitudinal diameter (SLD), seed equatorial diameter (SED), fruit weight (FW), and seed weight (SW), obtained for 198 E. edulis accessions by employing the restricted maximum-likelihood (REML) method.

\begin{tabular}{ccccccc}
\hline SV & FLD $(\mathrm{mm})$ & FED $(\mathrm{mm})$ & SLD $(\mathrm{mm})$ & SED $(\mathrm{mm})$ & FW $(\mathrm{g})$ & SW $(\mathrm{g})$ \\
\hline PPE & $6800.03^{+}$ & $7122.95^{+}$ & $5634.26^{+}$ & $6109.16^{+}$ & $-2836.53^{+}$ & $-7025.71^{+}$ \\
FM & $74.40^{++}$ & $499.68^{++}$ & $-1470.60^{++}$ & $-593.80^{++}$ & $-10362.27^{++}$ & $-13988.54^{++}$ \\
\hline LRT $\left(\chi^{2}\right)$ & $6725.63^{* *}$ & $6623.27^{* *}$ & $7104.86^{* *}$ & $6632.95^{* *}$ & $7525.75^{* *}$ & $6962.83^{* *}$ \\
\hline
\end{tabular}

SV - Source of variation, PPE - permanent phenotypic effect (genetic causes + permanent environment), FM - full model, LRT likelihood ratio test.; ${ }^{+}$Deviance of the model fitted without the referenced effect; ${ }^{++}$Deviance of the full model fit; ** Significant by a $\chi^{2}$ test, with 1 degree of freedom at the $1 \%$-probability level.

These differences reflect the significant genetic variability amongst the E. edulis populations studied (Table 1). According to Resende (2002a), the deviance analysis procedure (DEVANA), which employs the $\chi^{2}$ statistic to determine the significance of the LRT, is scientifically recommended for the analysis of the random effects of a model because it evaluates the level of variability in the studied random effects.

The coefficients of repeatability obtained for the six variables were all greater than 0.78
(Table 2) and, thus, indicate high repeatability according to classification by Resende (2002b), wherein coefficients of repeatability greater than 0.6 are considered high.

The coefficients of repeatability ranged from 0.78 to 0.82 across all of the tested methods (Table 2), indicating a high similarity amongst the results of the tested methods, which not only demonstrates the reliability of the results (MANFIO et al., 2011) but also demonstrates a good level of 
genetic control for these traits (FERREIRA et al., 2005).

There were no differences amongst the estimated repeatability coefficients of the tested methods for the FLD, SED, FW, or SW, which were characterized by repeatability coefficients of 0.79 , $0.78,0.82$, and 0.80 , respectively (Table 2).

Table 2. Estimated coefficients of repeatability $(\hat{\mathrm{r}})$, coefficients of determination $\left(\hat{\mathrm{R}}^{2}\right)$, and numbers of necessary measurements $\left(\eta_{0}\right)$, as calculated using restricted maximum likelihood (REML), principal component, and structural analyses based on the correlation and covariance matrices amongst the repeated measurements (PCC, PCCV, SAC, and SACV) for the following characteristics: fruit longitudinal diameter (FLD), fruit equatorial diameter (FED), seed longitudinal diameter (SLD), seed equatorial diameter (SED), fruit weight (FW), and seed weight (SW). Each of the 198 E. edulis accessions was measured 25 times.

\begin{tabular}{|c|c|c|c|c|c|c|}
\hline Variable & Method & $\hat{\mathrm{r}}$ & $\hat{\mathrm{R}}^{2}(\%)$ & $\eta_{0}(90 \%)$ & $\eta_{0}(95 \%)$ & $\eta_{0}(99 \%)$ \\
\hline \multirow{5}{*}{ FLD (mm) } & REML & 0.79 & 98.93 & $2(2.44)$ & $5(5.15)$ & $27(26.86)$ \\
\hline & PCC & 0.79 & 98.94 & $2(2.42)$ & $5(5.10)$ & 27 (26.59) \\
\hline & PCCV & 0.79 & 98.94 & $2(2.42)$ & $5(5.10)$ & $27(26.57)$ \\
\hline & $\mathrm{SAC}$ & 0.79 & 98.94 & $2(2.42)$ & $5(5.11)$ & $27(26.62)$ \\
\hline & SACV & 0.79 & 98.93 & $2(2.43)$ & $5(5.14)$ & 27 (26.77) \\
\hline \multirow{5}{*}{ FED (mm) } & REML & 0.78 & 98.90 & $3(2.51)$ & $5(5.31)$ & $28(27.64)$ \\
\hline & PCC & 0.79 & 98.96 & $2(2.37)$ & $5(5.01)$ & $26(26.09)$ \\
\hline & PCCV & 0.78 & 98.91 & $2(2.47)$ & $5(5.22)$ & $27(27.17)$ \\
\hline & SAC & 0.79 & 98.95 & $2(2.39)$ & $5(5.04)$ & $26(26.25)$ \\
\hline & SACV & 0.78 & 98.90 & $3(2.50)$ & $5(5.28)$ & $28(27.53)$ \\
\hline \multirow{5}{*}{ SLD (mm) } & REML & 0.80 & 99.03 & $2(2.21)$ & $5(4.66)$ & $24(24.27)$ \\
\hline & PCC & 0.81 & 99.04 & $2(2.18)$ & $5(4.60)$ & $24(23.97)$ \\
\hline & PCCV & 0.80 & 99.04 & $2(2.18)$ & $5(4.61)$ & $24(24.01)$ \\
\hline & SAC & 0.80 & 99.04 & $2(2.18)$ & $5(4.61)$ & $24(24.00)$ \\
\hline & SACV & 0.80 & 99.03 & $2(2.20)$ & $5(4.64)$ & $24(24.18)$ \\
\hline \multirow{5}{*}{$\mathrm{SED}(\mathrm{mm})$} & REML & 0.78 & 98.89 & $3(2.52)$ & $5(5.32)$ & $28(27.74)$ \\
\hline & PCC & 0.78 & 98.91 & $2(2.48)$ & $5(5.24)$ & $27(27.33)$ \\
\hline & PCCV & 0.78 & 98.91 & $2(2.48)$ & $5(5.23)$ & $27(27.26)$ \\
\hline & SAC & 0.78 & 98.91 & $2(2.49)$ & $5(5.25)$ & $27(27.35)$ \\
\hline & SACV & 0.78 & 98.90 & $3(2.50)$ & $5(5.27)$ & $27(27.46)$ \\
\hline \multirow{5}{*}{ FW (g) } & REML & 0.82 & 99.13 & $2(1.98)$ & $4(4.17)$ & $22(21.74)$ \\
\hline & PCC & 0.82 & 99.14 & $2(1.96)$ & $4(4.13)$ & $22(21.51)$ \\
\hline & PCCV & 0.82 & 99.14 & $2(1.95)$ & $4(4.13)$ & $22(21.50)$ \\
\hline & SAC & 0.82 & 99.14 & $2(1.96)$ & $4(4.13)$ & $22(21.53)$ \\
\hline & SACV & 0.82 & 99.13 & $2(1.97)$ & $4(4.15)$ & $22(21.65)$ \\
\hline \multirow{5}{*}{ SW (g) } & REML & 0.80 & 98.99 & $2(2.29)$ & $5(4.83)$ & $25(25.18)$ \\
\hline & PCC & 0.80 & 99.00 & $2(2.26)$ & $5(4.78)$ & $25(24.90)$ \\
\hline & PCCV & 0.80 & 99.00 & $2(2.27)$ & $5(4.79)$ & $25(24.95)$ \\
\hline & SAC & 0.80 & 99.00 & $2(2.27)$ & $5(4.79)$ & 25 (24.94) \\
\hline & SACV & 0.80 & 99.00 & $2(2.28)$ & $5(4.82)$ & $25(25.11)$ \\
\hline
\end{tabular}


A high similarity amongst the tested methods was also reported by Manfio et al. (2011) for macaw palm fruit. However, higher repeatability values have been reported in studies with other palms, such as caiaué and African oil palm (CHIA et al., 2009), bacuri (SILVA et al., 2009), and peach palm (BERGO et al., 2013), using the principal component method based on covariance matrices.

For the FED variable, the coefficients of repeatability determined by the principal component and structural analysis methods based on the correlation matrices amongst the repeated measures (PCC and SAC) were 0.79, whilst those of the restricted maximum likelihood (REML), principal component, and structural analyses based on covariance matrix methods were 0.78 (Table 2). According to Cruz et al. (2012), the difference between the PCC and SAC methods is only conceptual, thus the estimates generated by the two methods tend to be similar.

For the SLD characteristic, the coefficient of repeatability was 0.81 for the principal component method based on correlation matrix amongst the repeated measurements (PCC), and of 0.80 for the other methods (Table 2).

The coefficient of determination was always greater than $98 \%$, for all of the variables analysed by all of the methods ( 25 measurements). To achieve reliabilities of $99 \%$ for the FLD, SW, SLD, and FW variables, 27, 25, 24, and 22 measurements would be necessary, respectively (same for all methods, Table 2). For the $99 \%$ reliability for the FED characteristic, the REML and SACV methods indicated the need for 28 measurements, whereas the PCCV technique indicated the need for 27 measurements. The PCC and SAC methods provided a lower number of measurements for the FED variable (26), whilst the REML method indicated a higher number of measurements for the SED variable (28) compared to the other methods (27) (Table 2).

The coefficients of determination estimated in this study were extremely high in magnitude (> 98\%) (RESENDE, 2002b); hence, the possibility of reducing the reliabilities of the estimates to $95 \%$ was assessed (MANFIO et al., 2011). Under this scenario (95\% reliability), five measurements would be necessary for the FLD, FED, SLD, SED, and SW variables, and four measurements for the FW variable, representing $80 \%$ and $84 \%$ reductions in the numbers of measurements, respectively (Table 2).

Through these results we observe the possibility of decreased sample size for fruit and seed variables aiming to predict the real value of juçara genotypes in natural environment. This fact should provide reduced time, labor and costs for future expeditions aiming the characterization of juçara genotypes. According to Chia et al. (2009), reductions in the evaluation period and the numbers of measurements should be pursued to save resources and time, within an acceptable level of precision levels.

In repeatability studies performed with other perennials, such as guarana (NASCIMENTO FILHO et al. 2009), plum tree/peach trees (DANNER et al. 2010), and peach palm (Bergo et al. 2013), the authors considered coefficients of determination of $90 \%$ when calculating the necessary numbers of measurements $\left(\eta_{0}\right)$. In this study, the use of a coefficient of determination of $90 \%$ results in a value of two for the necessary numbers of measurements for the FLD, SLD, FW, and SW variables, for all of the methods.

Considering a coefficient of determination of $90 \%$ for the FED and SED variables, the REML and SACV methods indicated the need for three measurements, whereas the other methods (PCC, PCCV, and SAC) indicated that only two measurements were necessary.

\section{CONCLUSIONS}

The results of the tested methods did not differ with regards to the estimated coefficients of repeatability for the longitudinal diameters of the fruits, equatorial diameters of the seeds, fruit weights and seed weights variables.

The estimated coefficients of repeatability and determination are greater than 0.78 and $98 \%$, respectively, for all of the variables analysed for all of the methods.

The collection of five measurements for the FLD, FED, SLD, SED, and SW variables and four measurements for the FW variable can achieve 95\% reliability. Two measurements can provide a degree of predictability of $90 \%$ for the FLD, SLD, FW, and SW variables.

\section{ACKNOWLEDGEMENTS}

We thank the Centre of Agricultural Sciences of the Federal University do Espírito Santo (Centro de Ciências Agrárias da Universidade Federal do Espírito Santo - CCA UFES) for providing the infrastructure, and the Espírito Santo Research Foundation (Fundação de Amparo à Pesquisa do Espírito Santo - FAPES) of the Brazilian Federal Agency for Support and Evaluation of Graduate Education (Coordenação de 
Aperfeiçoamento de Pessoal de Nível Superior CAPES/REUNI) and the Brazilian National Council for Scientific and Technological Development
(Conselho Nacional de Desenvolvimento Científico e Tecnológico - CNPq) for financial assistance and scholarship.

RESUMO: A juçara é uma planta de ocorrência da Mata Atlântica brasileira e apresenta grande importância ecologia para a biodiversidade e se encontra na lista de espécies ameaçadas de extinção. Os frutos são conhecidos como super frutos por apresentarem características químicas de grande importância. Devido a sua grande importância econômica e pelo baixo número de pesquisas com esta espécie, o primeiro passo é fazer o pré-melhoramento. Este consiste em caracterização morfológica, a qual é muito dispendiosa de tempo e mão de obra. Sendo assim, a diminuição do número de medições avaliadas por indivíduo é de suma importância durante as fases de pré-melhoramento e melhoramento. O objetivo deste trabalho foi obter estimativas dos coeficientes de repetibilidade e de determinação, predizer o número adequado de medições capaz de proporcionar níveis de certeza da predição do valor real dos indivíduos para cada uma das seis características analisadas de Euterpe edulis, e comparar diferentes métodos de estimação da repetibilidade. Foram mensuradas seis características nos frutos de juçara e posteriormente estimou-se a deviance, o coeficiente de repetibilidade, o coeficiente de determinação e o número de medições necessárias para uma predição adequada do valor real dos indivíduos. As metodologias utilizadas não diferem quanto à estimativa do coeficiente de repetibilidade para as características diâmetro longitudinal do fruto, diâmetro equatorial da semente, massa do fruto e massa da semente. Com 95\% de confiabilidade é possível utilizar quatro (4) medições para massa do fruto e cinco (5) medições para diâmetro longitudinal do fruto, diâmetro equatorial do fruto, diâmetro longitudinal da semente, diâmetro equatorial da semente e massa da semente.

PALAVRAS-CHAVE: Euterpe edulis. Melhoramento de plantas. Biometria.

\title{
REFERENCES
}

ABEYWARDENA, V. An application of principal component analysis in genetics. Journal of Genetics, Bangalore, v. 16, p. 27-51, 1972. http://dx.doi.org/10.1007/BF02984099

BARROSO, R. M; REIS, A.; HANAZAKI, N. Etnoecologia e etnobotânica da palmeira juçara (Euterpe edulis Martius) em comunidades quilombolas do Vale do Ribeira, São Paulo. Acta Botanica Brasilica, Belo Horizonte, v. 24, n. 2, p. 518-528, 2010. http://dx.doi.org/10.1590/S0102-33062010000200022

BERGO, C. L.; NEGREIROS, J. R. S.; MIQUELONI, D. P.; LUNZ, A. M. P. Estimativas de repetibilidade de caracteres de produção em pupunheiras para palmito da raça Putumayo. Revista Brasileira de Fruticultura, Jaboticabal, v. 35, n. 3, p. 829-836, 2013. http://dx.doi.org/10.1590/S0100-29452013000300020

CEMBRANELI, F.; FISCH, S. T. V.; CARVALHO, C. P. Exploração sustentável da palmeira Euterpe edulis Martius no Bioma Mata Atlântica, Vale do Paraíba - SP. Revista Ceres, Viçosa, v. 56, n. 3, p. 233-240, 2009.

CHIA, G. S.; LOPES, R.; CUNHA, R. N. V.; ROCHA, R. N. C.; LOPES, M. T. G. Repetibilidade da produção de cachos de híbridos interespecíficos entre o caiaué e o dendezeiro. Acta Amazonica, Manaus, v. 39, p. 249254, 2009. http://dx.doi.org/10.1590/S0044-59672009000200001

\author{
CRUZ, C. D.; REGAZZI, A. J; CARNEIRO, P. C. S. Modelos biométricos aplicados ao melhoramento \\ genético. 4. ed. Viçosa-MG: UFV, 2012. 514p.
}

DANNER, M. A.; RASEIRA, M. C. B.; SASSO, S. A. Z.; CITADIN, I.; SCARIOT, S. Repetibilidade de peso de fruto e de duração do ciclo em ameixeira e pessegueiro. Pesquisa Agropecuária Brasileira, Brasília, v. 45, n. 8, p. 872-878, 2010. http://dx.doi.org/10.1590/S0100-204X2010000800013

FADINI, R. F.; FLEURY, M.; DONATTI, C. I.; GALETTI, M. Effects of frugivore impoverishmentand seed predators on the recruitment of a keystone palm. Acta Oecologica, Pousadas, v. 35, n. 2, p. 188-196, 2009. http://dx.doi.org/10.1016/j.actao.2008.10.001 
FARIAS NETO, J. T.; RESENDE, M. D. V.; OLIVEIRA, M. S. P. Seleção simultânea em progênies de açaizeiro irrigado para produção e peso do fruto. Revista Brasileira de Fruticultura, Jabuticabal, v. 33, n. 2 , p. 532-539, 2011. http://dx.doi.org/10.1590/S0100-29452011000200025

FELZENSZWALB, I.; MARQUES, M. R. C.; MAZZEI, J. L.; AIUB, C. A. F. Toxicological evaluation of Euterpe edulis: a potential superfruit to be considered. Food and Chemical Toxicology, Tarragona, v. 58, p. 536-544, 2013. http://dx.doi.org/10.1016/j.fct.2013.05.029

FERREIRA, A.; BARBOSA, M. H. P.; CRUZ, C. D.; HOFFMANN, H. P.; VIEIRA, M. A. S.; BASSINELLO, A. I.; SILVA, M. F. Repetibilidade e número de colheitas para seleção de clones de cana-de-açúcar. Pesquisa Agropecuária Brasileira, Brasília, v. 40, n. 8, p. 761-767, 2005. http://dx.doi.org/10.1590/S0100204X2005000800005

FIGUEREDO, M. J. M.; FERREIRA, T. A; SILVA, A. R. Z.; HELM, C. V.; HANSEL, F. A. Metodologia para obtenção de antocianinas de frutos de juçara (Euterpe edulis). Comunicado Técnico, Colombo-PR, n. 209, dez. 2008.

GANEM, R. S. (Org.). Conservação da biodiversidade: legislação e políticas públicas. Brasília: Câmara dos Deputados, Ed. Câmara, 2010. Série Memória e análise de leis, n. 2, 437p.

GATTI, M. G.; CAMPANELLO, P. I.; GOLDSTEIN, G. Growth and leaf production in the tropical palm Euterpe edulis: light conditions versus developmental constraints. Flora, Freiberg, v. 206, p. 742-748, 2011. http://dx.doi.org/10.1016/j.flora.2011.04.004

GENINI, J.; GALETTI, M.; MORELLATO, L. P. C. Fruiting phenology of palms and trees in an Atlantic rainforest land-bridge island. Flora, Freiberg, v. 204, p. 131-145, 2009. http://dx.doi.org/10.1016/j.flora. 2008.01.002

MANFIO, C. E.; MOTOIKEI, S. Y.; SANTOS, C. E. M.; PIMENTEL, L. D.; QUEIROZ, V.; SATOI, A. Y. Repetibilidade em características biométricas do fruto de macaúba. Ciência Rural, Santa Maria, v. 41, n. 1, p.70-76, 2011. http://dx.doi.org/10.1590/S0103-84782011000100012

MANSOUR, H.; NORDHEIM, E. V.; RULEDGE, J. J. Estimators of repeatability. Theoretical and Applied Genetics, Vechta, v. 60, p. 151 - 156, 1981. http://dx.doi.org/10.1007/BF00264520

MORRISON, D. F. Multivariate statistical methods. New Delhi: McGraw-Hill Book, 1976. 415p.

NASCIMENTO FILHO, F. J.; ATROCH, A. L.; CRUZ, C. D.; CARNEIRO, P. C. S. Repetibilidade da produção de sementes em clones de guaraná. Pesquisa Agropecuária Brasileira, Brasília, v. 44, n. 6, p. 605612, 2009. http://dx.doi.org/10.1590/S0100-204X2009000600009

PATTERSON, H. D.; THOMPSON, R. Recovery of inter-block information when block sizes are unequal. Biometrika, Oxford , v. 58 n. 3, p. 545-54, 1971. http://dx.doi.org/10.1093/biomet/58.3.545

RESENDE, M. D. V. Genética Biométrica e Estatística no Melhoramento de Plantas Perenes. Brasília: Embrapa Informação Tecnológica, 2002b. 975 p.

RESENDE, M. D. V. SELEGEN-REML/BLUP - Seleção genética computadorizada: manual do usuário. Colombo: Embrapa - CNPF, p. 67, 2002a.

ROCHA, R. B.; RAMALHO, A. R.; TEIXEIRA, A. L.; LAVIOLA, B. G.; SILVA, F. C. G.; MILITÃO, J. S. L. T. Eficiência da seleção para incremento do teor de óleo do pinhão-manso. Pesquisa Agropecuária Brasileira, Brasília, v. 47, n. 1, p. 44-50, 2012. http://dx.doi.org/10.1590/S0100-204X2012000100007 
RUTLEDGE, J. J. A scaling which remove bias of Abeywardena's estimator of repeatability. Journal of Genetics, Bangalore, v. 61, p. 247-250, 1974. http://dx.doi.org/10.1007/BF02986435

SEOANE, C. E. S.; KAGEYAMA, P. Y.; RIBEIRO, A. MATIAS, R.; REIS, M. S.; BAWA, K.; SEBBENN, A. M. Efeitos da fragmentação florestal sobre a imigração de sementes e a estrutura genética temporal de populações de Euterpe edulis Mart. Revista do Instituto Florestal, São Paulo, v. 17, n. 1, p. 25-43, 2005.

SANTOS, V. S.; NARDINI, V.; CUNHA Jr, L. C.; BARBOSA Jr, F.; TEIXEIRA, G. H. A. Identification of species of the Euterpe genus by rare earth elements using inductively coupled plasma mass spectrometry and linear discriminant analysis. Food Chemistry, Reading, v. 153, p. 334-339, 2014.

http://dx.doi.org/10.1016/j.foodchem.2013.12.057

SILVA, R. G.; CHAVES, M. C. L.; ARNHOLD, E.; CRUZ, C. D. Repetibilidade e correlação fenotípicas de caracteres do fruto de bacuri no estado do Maranhão. Acta Scientiarum Agronomy, Maringa, v. 31, p. 587591, 2009. http://dx.doi.org/10.4025/actasciagron.v31i4.723

TEAM, R. C. A language and environment for statistical computing. R Foundation for Statistical Computing, Vienna, Austria, 2015. Disponível em: <http://www.R-project.org/>. Acesso em: 09 de fevereiro de 2015. 